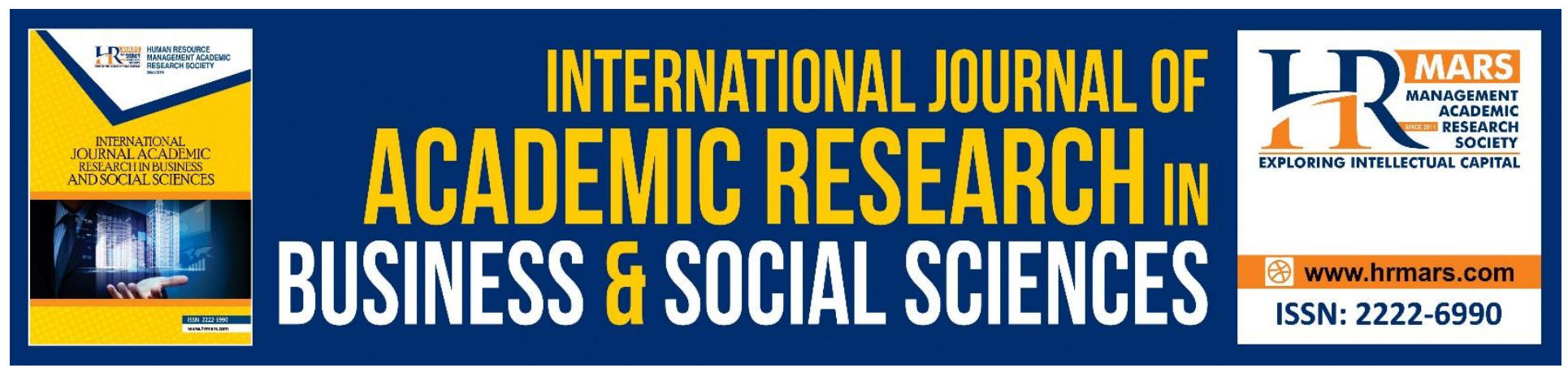

\title{
Job Characteristics and Job Satisfaction among Office Workers: The Mediating Role of Distributive Justice
}

Nor Azmawati Husain, Norlela Abas, Nurul Azrin Ariffin, Norshiba Norhisham

To Link this Article: http://dx.doi.org/10.6007/IJARBSS/v10-i9/7828

DOI:10.6007/IJARBSS/v10-i9/7828

Received: 11 June 2020, Revised: 13 July 2020, Accepted: 18 August 2020

Published Online: 28 September 2020

In-Text Citation: (Husain, Abas, Ariffin, Norhisham, 2020)

To Cite this Article: Husain, N. A., Abas, N., Ariffin, N. A., Norhisham, N. (2020). Job Characteristics And Job Satisfaction Among Office Workers: The Mediating Role Of Distributive Justice. International Journal of Academic Research in Business and Social Sciences. 10(9), 494-508.

Copyright: (C) 2020 The Author(s)

Published by Human Resource Management Academic Research Society (www.hrmars.com)

This article is published under the Creative Commons Attribution (CC BY 4.0) license. Anyone may reproduce, distribute, translate and create derivative works of this article (for both commercial and non-commercial purposes), subject to full attribution to the original publication and authors. The full terms of this license may be seen

at: http://creativecommons.org/licences/by/4.0/legalcode

Vol. 10, No. 9, 2020, Pg. 494 - 508

http://hrmars.com/index.php/pages/detail/IJARBSS

JOURNAL HOMEPAGE

Full Terms \& Conditions of access and use can be found at

http://hrmars.com/index.php/pages/detail/publication-ethics 


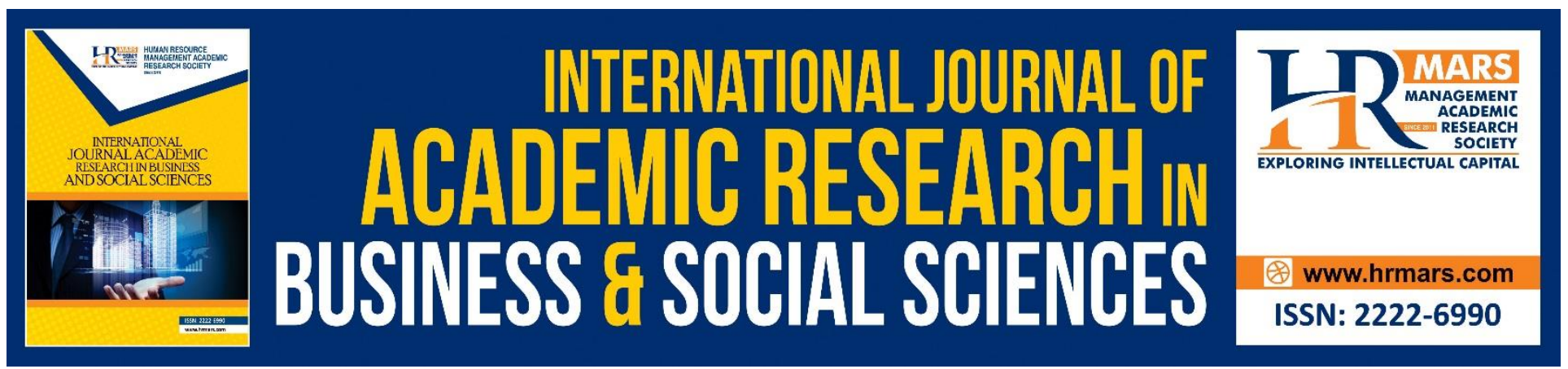

\title{
Job Characteristics and Job Satisfaction among Office Workers: The Mediating Role of Distributive Justice
}

\section{Nor Azmawati Husain ${ }^{1}$, Norlela Abas ${ }^{1}$, Nurul Azrin Ariffin ${ }^{3}$, Norshiba Norhisham ${ }^{2}$}

${ }^{1}$ Department of Management and Marketing, Faculty of Business Management, Universiti Teknologi MARA (UiTM) Melaka Kampus Jasin, 77300 Merlimau Melaka, Malaysia, ${ }^{2}$ Department of Human Resource Management, Faculty of Business Management, Universiti Teknologi MARA (UiTM) Melaka Kampus Bandaraya Melaka,110 Off Jalan Hang Tuah,75300 Bandaraya Melaka, Malaysia, ${ }^{3}$ Department of International Business, Faculty of Business Management, Universiti Teknologi MARA (UiTM) Melaka Kampus Bandaraya Melaka,110 Off Jalan Hang Tuah,75300 Bandaraya Melaka, Malaysia.

\begin{abstract}
Job characteristics theory suggests five elements that benefit job satisfaction among employees. Using social exchange theory (SET), we hypothesize, the perception of distribution fairness will mediate the effect of autonomy and task identity on job satisfaction among office workers. 97 data collected on office workers from single organisation. Data analysed using hierarchical regression analysis. In support with the hypotheses, the findings demonstrate significant association between autonomy, task identity and distributive fairness with job satisfaction. The employees that have adequate job autonomy and acknowledge based on their effort will have higher satisfaction if they perceived the organisation practise fair rewards distribution. This study provide evidence on the role of distributive fairness as mediator in present context
\end{abstract}

Keywords: Autonomy, Task Identity, Distributive Fairness, Office Workers, Job Satisfaction.

\section{Introduction}

Job satisfaction is described as "pleasurable or positive emotional state, resulting from the appraisal of one job experiences (Locke, 1976, p. 1300). Although plethora study evidenced on higher job satisfaction enhance job performance (Giles, Parker, Mitchell \& Conway, 2017) compared to other organisational behaviour such as job commitment (Shore \& Martin, 1989), and meta-analysis by Judge, Thoresen, Bono and Patton (2001) also proved the significant linkage between job satisfaction and job performance across 16 studies. However most of organisation seems to less focus on this underpinning issue as JobStreet.com reported in 2015 only 26\% of workers in Malaysia are satisfied with their job. In United Kingdom, similar issues were faced when studies found United Kingdom has 
INTERNATIONAL JOURNAL OF ACADEMIC RESEARCH IN BUSINESS AND SOCIAL SCIENCES Vol. 10, No. 9, 2020, E-ISSN: 2222-6990 @ 2020 HRMARS

the lowest level of job satisfaction (67.2\%) across eight countries(O'Grady, 2017). These alarming figures triggered us to examine more on antecedents of job satisfaction from various perspectives.

Job satisfaction among office workers still remain studied until now. Although the percentage of office workers is small, office workers productivity play an important role as it can affect the organisation performance (Haynes, 2007) For example, office workers amounted $10 \%$ from total 31,996 (thousand) workers in United Kingdom (UK Labour Force Survey, 2017). Meanwhile, 8.2\% of workers in Malaysia are categorised under office workers (International Labour Organization (ILO), 2017). Office workers are those who performed varieties of administration and office duties (Szeto, Straker \& Raine, 2002). For example, updating records, answering phone calls, processing orders, collecting payments and doing paperwork. Satisfied workers is mentioned to voluntarily invest effort in performing their job effectively (Lawler \& Hall, 1970; Yang \& Hung, 2017). Hence, to make sure organisation performed well, management need to ensure their workers satisfied with their job.

Many factors influence job satisfaction. According to job satisfaction theory, workers will feel motivated, happy with their work, will have lower absenteeism rates and also low turnover if five core work dimension being combined called job characteristics (Fried \& Ferris, 1987). The relationship of job characteristics towards satisfaction occurs when the job is planned with a high skills variety, clear task identity, clear tasks significance, giving broad autonomy and always giving feedback to job incumbents (Hadi \& Adil, 2010). Hackman and Oldham (1976) suggested the earliest job characteristics which comprised of five dimensions namely; skill variety, task identity, task significance, autonomy, and feedback. Fried and Ferris (1987) in their meta-analysis described job characteristics model using 5 dimensions across industries, first is skill variety that refers to level of variability in skill required to accomplish task. Second, task identity how much influence on the task in term of the whole process of task completion from early to end stage. Third, task significance describes as task importance to employees, others and organisation. Next is autonomy. It refers degree of freedom and control on the whole task completion. And lastly is feedback being when the task allows feedback from other on the task effectiveness. Besides these elements, distributive justice also been mentioned as one of the indicator that influence job satisfaction (Abu Elanain, 2009; McFarlin \& Sweeney, 1992). Perception on treating employee fairly is encouraging many positive organisational outcomes such as commitment and organisational behaviour (Moorman, Niehoff \& Organ, 1993).

The study is purposely to investigate the role of distributive justice in job characteristics and job satisfaction relationship among office worker. Previous study mainly focused on job satisfaction from perspective of internal and external motivation (Eskildsen, Kristensen \& Westlund, 2004; Tella, Ayeni \& Popoola, 2007), personality traits (Harari, Thompson \& Viswesvaran, 2018; Ilies \& Judge, 2002). But studies on job characteristics of office workers are little to be found. Most studies concerning office workers are dominantly focused on physical work environment such as the space and building (Shin, Jeong \& Park, 2018), ergonomic strains such as back pains (Chen, O'Leary \& Johnston, 2018). Moreover, employee's job satisfactions play an important role in every organization. For example, if workers satisfy with their job, it will contribute to the customers' satisfaction as employee will give excellent service to the customer (Abdolshah, Zadeh, Talei, Shirzadi \& Khatibi, 2018) 
INTERNATIONAL JOURNAL OF ACADEMIC RESEARCH IN BUSINESS AND SOCIAL SCIENCES Vol. 10, No. 9, 2020, E-ISSN: 2222-6990 @ 2020 HRMARS

\section{Literature Review}

\section{Factors Affecting Job Satisfaction}

Cheung and Wu (2012) described job satisfaction as "I am happy and satisfied with my current job". Job satisfaction is how employee feels about the job. It also stresses employee's psychological content. Another aspect influence job satisfaction is the job itself such as challenging job (Yang \& Hwang, 2014). Job satisfaction can be described as a various measures that resulted to overall job satisfaction, which affect employee's positive or negative feeling related to the job, and other various job satisfaction aspects, also their feelings toward job condition (Wickramasinghe, 2009). The outcomes of job characteristics varied across organisational outcomes including to ease job stress, enhance motivation, increase job satisfaction and affect competency of employees. For example, employee tends produce high quality of tasks, high motivation at work and satisfy with job if they have the opportunities to expand their range of skills in challenging task with direct autonomy. (Cheung et al., 2012). Thomas et al., (2004) argued that job characteristics would have a better prediction on job satisfaction than other rigid elements such as personality. The mechanism of job characteristics on job satisfaction are divided in two ways, such as intrinsic and extrinsic mechanism. Job satisfaction that affect intrinsic elements are when employee and experiencing feelings of accomplished at work. While, extrinsic is derived from the rewards associated with job accomplishment (i.e. compensation and also job security) (Bhuian \& Omar, 2006). Another elements of that might affect job satisfaction is the level of burnout. Lower levels of burnout resulted to greater job satisfaction (Kim, Ra, Park \& Kwon, 2017). For instance, employees with high level of satisfaction tend to remain in their jobs longer. As stated by Wickramasinghe (2009), higher level satisfaction resulted to better job turnover.

\section{Autonomy and Job Satisfaction}

Freedom to adopt autonomy also enhance job satisfaction (Hauff, Richter \& Tressin, 2015), increase employee's job performance (Simmering, Colquitt, Noe \& Porter, 2003), helps in employees to adapt with challenging job Rudolph, Katz, Lavigne and Zacher (2017). Autonomy is described as the extent to which workers have a freedom to do what they want on the job (Bhuian, Al-Shammari \& Jefri, 1996). In other words, the supervisors and institutions valued their ideas and inputs (Jin, Sun, Jiang, Wang \& Wen, 2018). Hackman and Oldham (1976) argued freedom to make decision is vital for employees' success. Such as employees who have high jobs autonomy perceive they are important hence responsible in the success or failure of the task including deciding on how to perform their job well. For example, studies conducted among IT professionals has also been suggested autonomy and flexibility in job able to reduce the job stress (Ahuja, Chudoba, Kacmar, McKnight \& George, 2007).

Job autonomy can be one of the significant factors for many people to look for a job. Having a certain degree of control in what they do and how they do it determine how much they satisfied with the job (Jin et al., 2018). For example, employee able to feel self-directed and then proud of their job when they have control over their job, motivate employee to try new ideas and learn from consequences, and expand their skills (Ali, Said, Kader, Ab Latif \& Munap, 2014), able to complete work tasks in a more comfortable manner and feel responsible for achieving higher performance (Cerasoli, Nicklin \& Ford, 2014) better teamwork and personal growth, better morale and greater responsibility towards work. Less job autonomy in work lead to poor personal achievement and induce negative attitude resulted to burnout. In fact, job satisfaction will increase when a high level 
INTERNATIONAL JOURNAL OF ACADEMIC RESEARCH IN BUSINESS AND SOCIAL SCIENCES Vol. 10, No. 9, 2020, E-ISSN: 2222-6990 @ 2020 HRMARS

of job autonomy being given to them as it means that they are very trusted by their supervisors or organizations.

H1 : There is a relationship between autonomy and job satisfaction

\section{Task Identity and Job Satisfaction}

Task identity has functional affect various outcomes at works (Abu Elanain, 2009) . Job with high level of task identity permit the employee to evolve together with the outcomes or product as they contribute at all stage (Pee \& Chua, 2015). It reduces the feeling to anxiety due to not having enough information and knowledge about the outcomes since the employees know from the scratch. As task identity increases, workers are able to evaluate their work quality(Saavedra \& Kwun, 2000). Higher level of task identity will enhance employee's job performance and lower level of stress (Brooks \& Califf, 2017). Higher level of task identity affect many organisational outcomes such as job meaningfulness and motivation at work (Ali et al., 2014), feeling pride in the outcome of the job (Johari \& Yahya, 2016). Therefore, task identity important to increase job satisfaction.

H2 : There is a relationship between task identity and job satisfaction.

\section{The Relationship between Job Characteristics, Distributive Justice and Job Satisfaction}

One way to explain the antecedents of job satisfaction is using the occupational stress models. The present study used the job demand resource model (JD-R) (Bakker \& Demerouti, 2007; Demerouti, Bakker, Nachreiner \& Schaufeli, 2001) as a base model. The basic assumption of this model is that different occupational groups possess unique characteristics. Generally, the researchers categorized these factors into situational factors and individual factors (Crawford, LePine \& Rich, 2010). Situational factors can be categorised into two, namely job demands and job resources. It is hypothesized that job resource (task identity and autonomy) are likely to be resulted in several positive spiral outcomes and that support organizational goals. This includes an increase in work engagement (Bakker, Hakanen, Demerouti \& Xanthopoulou, 2007) and other positive organisational outcomes and it might have the similar affect to job satisfaction. The spiral effect of job resource (i.e. autonomy and task identity) might give positive perception not only to distributive fairness even it might positively influence organizational and workers outcomes (Hakanen, Schaufeli \& Ahola, 2008)

H3: There is a relationship between autonomy and distributive fairness

$\mathrm{H} 4$ : There is a relationship between task identity and distributive fairness

If an employee believes that the distribution of resources is fair and justice, the perception of fairness can increase job satisfaction (Strom, Sears \& Kelly, 2014). To support this assumption, it may refer to the social exchange theory (Blau, 1964) and conservation resource theory (COR) (Hobfoll, 1989), as workers that feel they perceive fairness are experiencing positive experiences. This will eventually accumulate and create a positive spiral of resources and affect the work engagement in an organisation. The distribution of fairness role as mediators have been discussed through the social exchange theory (SET) (Blau, 1964), where the fairer the opinion regarding distributive fairness in an organisation, the stronger the influence in strengthening the job resources, thus improving job satisfaction among workers. For instance, studies conducted among public servants in India provided evidence on how perceived fairness has a link with job satisfaction ((Biswas, Varma \& Ramaswami, 
INTERNATIONAL JOURNAL OF ACADEMIC RESEARCH IN BUSINESS AND SOCIAL SCIENCES Vol. 10, No. 9, 2020, E-ISSN: 2222-6990 @ 2020 HRMARS

2013). Distributive fairness is considered to be one of the potential job resources among public administrators (Ghosh, Rai \& Sinha, 2014) that is likely in affecting the level of work engagement.. We expect a similar mechanism applied to job characteristics and job satisfaction linkage in this study. Therefore, below is the hypothesis that was formulated:

H5: Distributive fairness is positively related to job satisfaction

H6: Distributive fairness mediates the relationship between autonomy and job satisfaction H7: Distributive fairness mediates the relationship between task identity and satisfaction

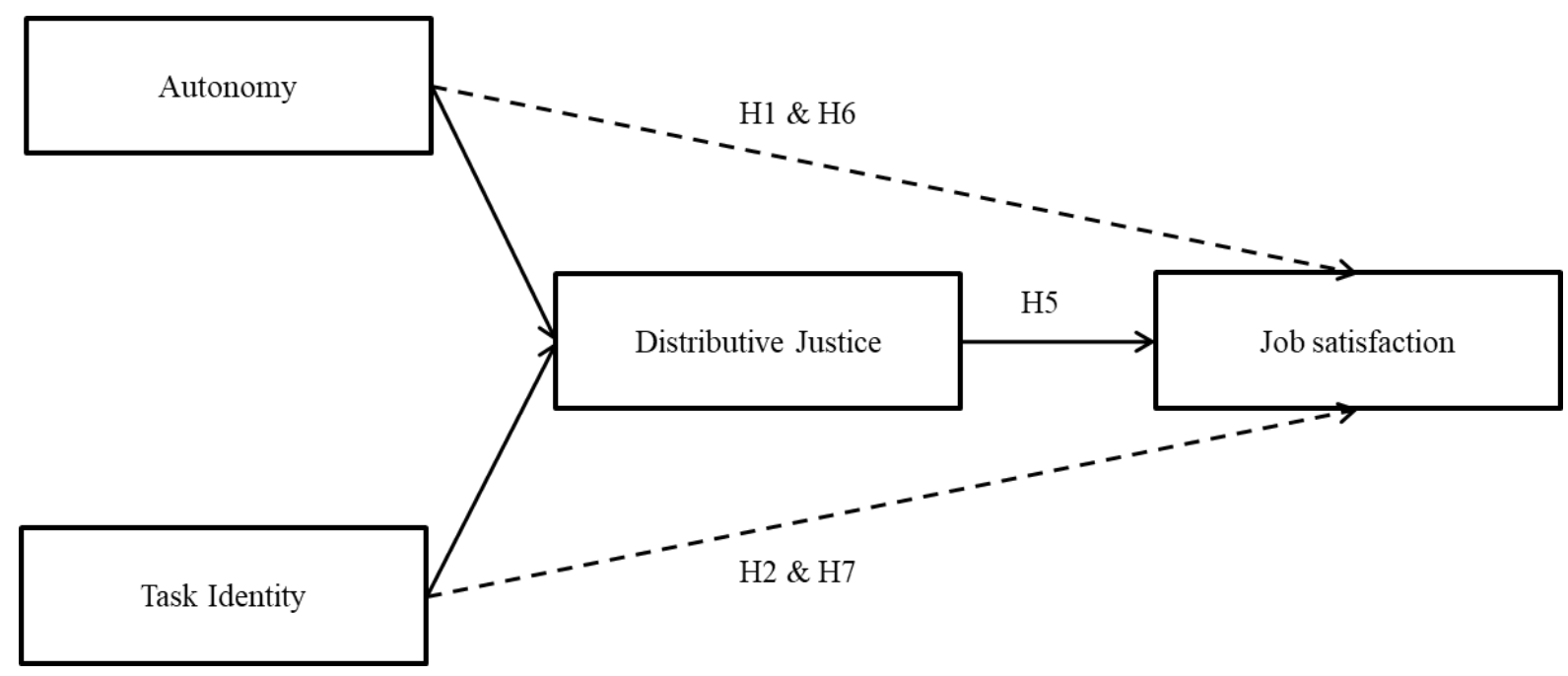

Figure 1: Proposed model

\section{Methods}

The data collection process began in October 2017 and was completed in November 2017. Out of 97 of respondents, $77.3 \%$ are males and $22.7 \%$ are females (SD =.42). mean ranged age of respondents are 26-35 years old (SD = 1.04). In addition, for the years of working experience, $42.3 \%$ of the respondent has been worked in SAJ Ranhill branch in Segamat, Johor, Malaysia. for less than 10 years which is the highest percentage. $23.7 \%$ of the respondent has been worked for $11-20$ years. While $34 \%$ of the respondents have been worked more than 21 years (SD $=.88$ ). Furthermore, for the education level of respondents, $4.1 \%$ of respondents have PMR, and the highest level is SPM which consist of $35.1 \%$ (SD =1.57) 
INTERNATIONAL JOURNAL OF ACADEMIC RESEARCH IN BUSINESS AND SOCIAL SCIENCES

Vol. 10, No. 9, 2020, E-ISSN: 2222-6990 @ 2020 HRMARS

Table 1: Demographic profile of respondents

\begin{tabular}{|c|c|c|}
\hline & Frequency & Percentage \\
\hline \multicolumn{3}{|l|}{ Gender } \\
\hline Male & 75 & 77.3 \\
\hline Female & 22 & 22.7 \\
\hline Total & 97 & 100 \\
\hline \multicolumn{3}{|l|}{ Age } \\
\hline$\leq 25$ & 11 & 11.3 \\
\hline $26-35$ & 21 & 21.6 \\
\hline $36-45$ & 29 & 29.9 \\
\hline $46 \geq$ & 36 & 37.1 \\
\hline Total & 97 & 100 \\
\hline \multicolumn{3}{|c|}{ Length of service (years) } \\
\hline $1-10$ & 41 & 42.3 \\
\hline $11-20$ & 23 & 23.7 \\
\hline $21 \geq$ & 33 & 34.0 \\
\hline Total & 97 & 100 \\
\hline \multicolumn{3}{|c|}{ Education level } \\
\hline PMR & 4 & 4.1 \\
\hline SPM & 34 & 35.1 \\
\hline STPM & 8 & 8.2 \\
\hline Certificate & 13 & 13.4 \\
\hline Diploma & 26 & 26.8 \\
\hline Degree & 12 & 12.4 \\
\hline Total & 97 & 100 \\
\hline
\end{tabular}

The purpose of this study is to examine the relationship between five core job characteristics with job satisfaction among office workers. These scale were taken from previous studies that examined job satisfaction and five core job characteristics. Existing scales were translated into Malay by using back-translation method (Brislin, 1986).

For the questionnaire, job satisfaction was measured with 14 questions based on Herzberg's two-factor theory. However, after conduct a factor analysis, two questions have been deleted. This reliable is reliable to be measured $(\alpha=.94)$. E.g: "Are you satisfied with the achievement of your personal job?"

Next, five core job characteristics was measured using The Work Design Questionnaire (WDQ) by (Morgeson, 2006). For task identity, no items were deleted. Four question being used. This reliable to be measured ( $\alpha=0.89)$. E.g: "This task allow me to complete the work I begin".In addition, autonomy has nine question, and only 6 question left. This reliable to be measured ( $\alpha=.89)$. E.g: "This work allows me to make many decisions myself". 
INTERNATIONAL JOURNAL OF ACADEMIC RESEARCH IN BUSINESS AND SOCIAL SCIENCES

Vol. 10, No. 9, 2020, E-ISSN: 2222-6990 @ 2020 HRMARS

We used the IBM SPSS Statistics (SPSS) software package to see the inter-correlations between variables. Harman's single factor test was conducted through the exploratory factor analysis (EFA) in SPSS to assess the common method variance (Podsakoff \& Organ, 1986) These data were free from the common method variance as the variance explained by a single factor at $12.87 \%$ was less than $50 \%$. Then, we used a standard hierarchical multiple regression analysis to examine the main and interaction effect proposed in each hypothesis, as recommended by (Cohen, 1983). To test our mediation hypothesis, we employed steps from (Baron \& Kenny, 1986). To test for the indirect effect, we used the Monte Carlo Simulation (Selig \& Preacher, 2008). With the confidence interval (Cl) value of 95 , not including zero, this indicates a statistical significance.

\section{Results}

Table 2: Means, Standard. Deviation (SD), and Inter-Correlations between study

\begin{tabular}{lllllll}
\hline & Mean & SD & 1 & 2 & 3 & 4 \\
\hline Job_Satisfaction & 4.07 & .58 & - & & & \\
DistributiveJustice & 4.17 & .64 & $.61^{* * *}$ & & & \\
Task_Identity & 4.16 & .55 & $.64^{* * *}$ & $.46^{* * *}$ & & \\
Autonomy & 3.95 & .60 & $.59^{* * *}$ & $.41^{*}$ & $.66^{*}$ & - \\
\hline
\end{tabular}

$\mathrm{N}=97 * \mathrm{p}<0.05, * * \mathrm{p}<0.01, * * * \mathrm{p}<0.001$

Table 4.1 shows there is significant, positive and strong relationship between task identity and job satisfaction $(r=.64, p<.001)$. In addition, there is significant, positive and strong relationship between autonomy and job satisfaction $(r=.59, p<.001)$. Lastly, there is significant, positive and strong relationship between distributive justice and job satisfaction $(r=.61, p<.001)$.

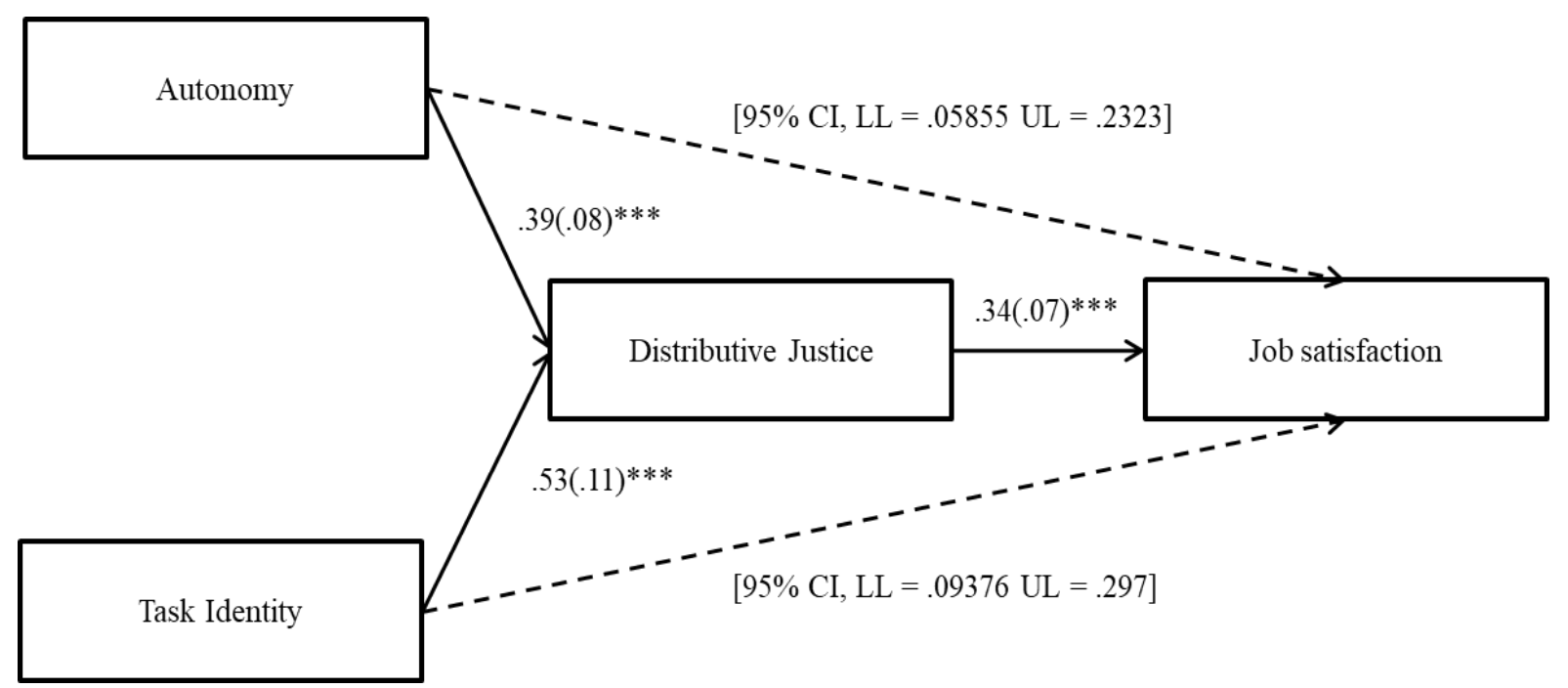

Figure 2: Results 
INTERNATIONAL JOURNAL OF ACADEMIC RESEARCH IN BUSINESS AND SOCIAL SCIENCES Vol. 10, No. 9, 2020, E-ISSN: 2222-6990 @ 2020 HRMARS

Table 3: Hierarchical regression analysis predicting job satisfaction

\begin{tabular}{llll}
\hline Step & 1 & 2 & 3 \\
\hline Task identity & $.69(.08)^{* * *}$ & $.49(.08)^{* * *}$ & $.35(.09)^{* * *}$ \\
Distributive Justice & & $.37(.07)^{* * *}$ & $.34(.07)^{* * *}$ \\
Autonomy & & & $.24(.09)^{*}$ \\
$\mathrm{R}^{2}$ & .41 & .54 & .57 \\
$\Delta \mathrm{R}^{2}$ & - & .13 & .03 \\
\hline
\end{tabular}

$\mathrm{N}=97 * \mathrm{p}<0.05, * * \mathrm{p}<0.01, * * * \mathrm{p}<0.001$

\section{Discussion}

This study purposely conducted to explain about the relationship between job characteristics and job satisfaction, and verified the role of distributive justice in the relationship between it. The findings show that only both job characteristics (autonomy and task identity) has positive significant relationship with job satisfaction and distributive justice.

First hypothesis is to identify the relationship between autonomy and job satisfaction. Based on the finding, it has found that the mean for autonomy is at 3.99 which indicates moderate relationship with job satisfaction. As expected, autonomy affect job satisfaction. This is because, the results indicate that autonomy has positive relationship on job satisfaction with beta value at $\beta=.24(.09)$ and it has a positive relationship towards job satisfaction and have significant at $p<0.001$. This finding supported by Abu Elanain (2009) which indicates that autonomy is correlated positively with job satisfaction. According to Simmering et al. (2003), higher level of autonomy will increase employee's job performance cause of satisfied with their job. Hence, this result has supported the hypothesis about the relationship between autonomy and job satisfaction.

Second hypothesis to identify the relationship between task identity and job satisfaction. Based on the finding, it has found that the mean for task identity is at 4.16 which is indicate moderate relationship with job satisfaction. As expected, task identity affects job satisfaction. This is because, the results indicate that task identity has positive relationship on job satisfaction with beta value at $\beta=.35(.09)$ and it has a positive relationship towards job satisfaction and have significant at $p<0.001$. This finding supported by Ali et al. (2014) stated that task identity have significant with job satisfaction. According to Brooks and Califf (2017), higher level of task identity will enhance employee's job performance and lower level of stress. Hence, this result has proven the hypothesis about the relationship between task identity and job satisfaction.

Hypothesis three is supported where there is a significant direct association between autonomy and distributive fairness. Beta value at $\beta=.39(.1)$ and it has a positive relationship towards job satisfaction and have significant at $p<0.001$. our findings however contradict with studies conducted by Abu Elanain (2009) where they cannot provide evidence on the association between autonomy and job satisfaction.

Next is hypothesis four where we try to prove the relationship between task identity with distributive fairness. These findings was in line with studies conducted in Dubai by Abu Elanain (2009) where task identity and distributive justice proven to be directly related. Beta value at $\beta=.53(.11)$ and it has a positive relationship towards job satisfaction and have significant at $p<0.001$ 
INTERNATIONAL JOURNAL OF ACADEMIC RESEARCH IN BUSINESS AND SOCIAL SCIENCES Vol. 10, No. 9, 2020, E-ISSN: 2222-6990 @ 2020 HRMARS

Hypothesis five also supported where we able to provide evidence on direct association between distributive fairness and job satisfaction. Beta value at $\beta=.57(.07)$ and it has a positive relationship towards job satisfaction and have significant at $p<0.001$. Similar findings provided by studies conducted in most of Eastern countries such as (Abu Elanain, 2009; Almazrouei, Zacca, Evans and Dayan, 2018; Nadiri and Tanova, 2010). Fairness of employee received carried more stronger effect than other two organisational fairness (procedural and interactional) (Cohen-Charash \& Spector, 2001; Nadiri \& Tanova, 2010). Contradict with many studies conducted in western countries such as Lambert, Hogan and Griffin (2007) where they not able to provide evidence on the effect of distributive justice on job satisfaction among correctional officers.

Hypothesis six is supported where distributive fairness mediates the relationship between autonomy and job satisfaction. Monte Carlo simulation (Selig \& Preacher, 2008) provide the confidence interval (Cl) value of 95 , not including zero, this indicates a statistical significance $[95 \% \mathrm{Cl}, \mathrm{LL}=.05855 \mathrm{UL}=$ .2323]. this discussion is been supported by Younts and Mueller (2001) where distributive justice mediate the relationship on minister pay satisfaction. Regardless of level of occupation, as long as employees perceived what they received is fair then it able to influence the type of emotions of employees at workplace (i.e. job satisfaction). Spell (2009) in other hand provide proved on the role of distributive fairness in buffering the effect of autonomy on job satisfaction.

Last is hypothesis seven where finding provides support on the mediator role of distributive fairness between task identity and job satisfaction. The value after run the Monte Carlo simulation is $95 \% \mathrm{Cl}$, $\mathrm{LL}=.09376 \mathrm{UL}=.297]$. This indicate the confidence interval $(\mathrm{Cl})$ value of 95 , not including zero, this indicates a statistical significance. Clayton and Opotow (2003) highlight the significant of identity in reasoning fairness effect. Different people perceived justice in different way and weight. Although less studies highlighted task identity and its effect on employees outcomes, few studies such as (Hoonakker, Marian \& Carayon, 2004) provide proves that task identity affect job satisfaction through gender and job type among IT officer. Employees that involved entirely in the process of work will be satisfied with their work if they think they receive fair treatment equivalent to the effort they invest. Many scholar supported these findings where rewards that based on individual performance is more significant in increasing job satisfaction (Janssen, 2001).

\section{Conclusion And Recommendations}

Despite the evidence provided on the effect of job characteristics and job satisfaction, the roles of distributive justice has not been thoroughly examined among office workers. The most important findings of this study is distributive justice significantly mediate the link between job characteristics elements such as autonomy and task identity and job satisfaction. In line with Social Exchange Theory (SET), distributive justice is a possible mechanism that brought the positive affect of autonomy and task identity on job satisfaction among office workers. Present study also provides support on that distributive justice as significant resource in social exchange between organisational parties such as employees - organisation.

In particular, the result largely support our hypotheses as our findings suggest organisational should take proper control over allocating rewards according to individual contribution as it will affect employee's satisfaction. Failure to practise fairness in distributive justice increase job stress level, for example job stress among correctional officers increase due to feeling of under rewards on matters related to organisation justice element such as distributive justice (Lambert et al., 2007). 
INTERNATIONAL JOURNAL OF ACADEMIC RESEARCH IN BUSINESS AND SOCIAL SCIENCES Vol. 10, No. 9, 2020, E-ISSN: 2222-6990 @ 2020 HRMARS

Besides, in job design, adequate autonomy and clear task identity are vital while maintaining fairness in distributing rewards is valued and effective. Organisation should seek to job design that offer task identity so employee find their work interesting and meaningful. By that, it permit them to perform variety of tasks that require a broad knowledge, skills and abilities, so it will make the employee feel proud and have a sense of achievement when that particular job is well done. While giving employees autonomy in areas such as scheduling work and determining how and when to do job tasks will creates independent employees and they will gain greater control over the planning and implementation of their tasks. Previous study highlighted autonomy increase homecare workers' job satisfaction (Barken et al., 2018)

\section{Limitation of Study}

This study has a few limitations. First, the findings based on cross-sectional data. Thus we causality is impossible to be proposed. Evidence is based on correlational only. Second, limited number of data can exposed the data to bias. Third limitation is generalizability of the result. The sample only used one organisation as referent for office workers. Different organisation might possess different job characteristics affect

\section{Acknowledgment}

The authors are thankful to the Ranhill (SAJ) for allowing the data collection to be carried out at their organisation for use in this research

\section{References}

Abdolshah, M., Zadeh, E. J., Talei, R., Shirzadi, A., \& Khatibi, A. M. (2018). Does Job Satisfaction Always Affect Customer Satisfaction?: Case Study-(SSIO) Social Security Insurance Organization in Tehran. International Journal of Customer Relationship Marketing and Management (IJCRMM), 9(2), 62-78. doi: 10.4018/IJCRMM.2018040104

Abu Elanain, H. M. (2009). Job characteristics, work attitudes and behaviors in a non-western context: Distributive justice as a mediator. Journal of Management Development, 28(5), 457-477. doi: https://doi.org/10.1108/02621710910955985

Ahuja, M. K., Chudoba, K. M., Kacmar, C. J., McKnight, D. H., \& George, J. F. (2007). IT road warriors: Balancing work-family conflict, job autonomy, and work overload to mitigate turnover intentions. Mis Quarterly, 1-17. doi: 10.2307/25148778

Ali, S. A. M., Said, N. A., Kader, S. F. A., Ab Latif, D. S., \& Munap, R. (2014). Hackman and Oldham's job characteristics model to job satisfaction. Procedia-Social and Behavioral Sciences, 129, 46-52. doi: https://doi.org/10.1016/j.sbspro.2014.03.646

Almazrouei, H. S., Zacca, R., Evans, J. M., \& Dayan, M. (2018). Great expectations: The moderating role of pre-departure opinion on the relationship between organizational justice and expatriates' commitment and job satisfaction. Journal of Global Mobility: The Home of Expatriate Management Research, 6(2), 178-193. doi: https://doi.org/10.1108/JGM-07-20170031

Bakker, A. B., \& Demerouti, E. (2007). The job demands-resources model: State of the art. Journal of managerial psychology, 22(3), 309-328. doi: 10.1108/02683940710733115 
INTERNATIONAL JOURNAL OF ACADEMIC RESEARCH IN BUSINESS AND SOCIAL SCIENCES Vol. 10, No. 9, 2020, E-ISSN: 2222-6990 @ 2020 HRMARS

Bakker, A. B., Hakanen, J. J., Demerouti, E., \& Xanthopoulou, D. (2007). Job resources boost work engagement, particularly when job demands are high. Journal of Educational Psychology, 99(2), 274.

Barken, R., Denton, M., Sayin, F. K., Brookman, C., Davies, S., \& Zeytinoglu, I. U. (2018). The influence of autonomy on personal support workers' job satisfaction, capacity to care, and intention to stay. Home Health Care Services Quarterly, 37(4), 294-312. doi: 10.1080/01621424.2018.1493014

Baron, R. M., \& Kenny, D. A. (1986). The moderator-mediator variable distinction in social psychological research: Conceptual, strategic, and statistical considerations. Journal of Personality and Social Psychology, 51(6), 1173-1182. doi: 10.1037/0022-3514.51.6.1173

Bhuian, S. N., Al-Shammari, E. S., \& Jefri, O. A. (1996). Organizational commitment, job satisfaction and job characteristics: An empirical study of expatriates in Saudi Arabia. International Journal of Commerce and Management, 6(3/4), 57-80. doi: https://doi.org/10.1108/eb047336

Biswas, S., Varma, A., \& Ramaswami, A. (2013). Linking distributive and procedural justice to employee engagement through social exchange: a field study in India. The International Journal of Human Resource Management, 24(8), 1570-1587. doi: 10.1080/09585192.2012.725072

Blau, P. M. (1964). Exchange and power in social life: Transaction Publishers.

Brislin, R. W. (1986). Research instruments. Field methods in cross-cultural research, 8, 137-164.

Brooks, S., \& Califf, C. (2017). Social media-induced technostress: Its impact on the job performance of it professionals and the moderating role of job characteristics. Computer Networks, 114, 143-153. doi: https://doi.org/10.1016/j.comnet.2016.08.020

Cerasoli, C. P., Nicklin, J. M., \& Ford, M. T. (2014). Intrinsic motivation and extrinsic incentives jointly predict performance: A 40-year meta-analysis. Psychological Bulletin, 140(4), 980. doi: http://dx.doi.org/10.1037/a0035661

Chen, X., O'Leary, S., \& Johnston, V. (2018). Modifiable individual and work-related factors associated with neck pain in 740 office workers: a cross-sectional study. Brazilian journal of physical therapy. doi: https://doi.org/10.1016/j.bjpt.2018.03.003

Cheung, M. F., \& Wu, W.-P. (2012). Leader-member exchange and employee work outcomes in Chinese firms: the mediating role of job satisfaction. Asia Pacific Business Review, 18(1), 6581. doi: https://doi.org/10.1080/13602381.2010.535346

Clayton, S., \& Opotow, S. (2003). Justice and identity: Changing perspectives on what is fair. Personality and Social Psychology Review, 7(4), 298-310. doi: https://doi.org/10.1207/S15327957PSPR0704_03

Cohen-Charash, Y., \& Spector, P. E. (2001). The role of justice in organizations: A meta-analysis. Organizational Behavior and Human Decision Processes, 86(2), 278-321. doi: https://doi.org/10.1006/obhd.2001.2958

Cohen, J. (1983). Applied multiple regression/correlation analysis for the behavioral sciences.

Crawford, E. R., LePine, J. A., \& Rich, B. L. (2010). Linking job demands and resources to employee engagement and burnout: A theoretical extension and meta-analytic test. Journal of Applied Psychology, 95(5), 834-848. doi: 10.1037/a0019364

Demerouti, E., Bakker, A. B., Nachreiner, F., \& Schaufeli, W. B. (2001). The job demands-resources model of burnout. Journal of Applied Psychology, 86(3), 499. 
INTERNATIONAL JOURNAL OF ACADEMIC RESEARCH IN BUSINESS AND SOCIAL SCIENCES

Vol. 10, No. 9, 2020, E-ISSN: 2222-6990 @ 2020 HRMARS

Eskildsen, J. K., Kristensen, K., \& Westlund, A. H. (2004). Work motivation and job satisfaction in the Nordic countries. Employee relations, 26(2), 122-136. doi:

https://doi.org/10.1108/01425450410511043

Fried, Y., \& Ferris, G. R. (1987). The Validity of the Job Characteristics Model: A Review and MetaAnalysis. Personnel Psychology, 40(2), 287-322. doi: 10.1111/j.1744-6570.1987.tb00605.x

Ghosh, P., Rai, A., \& Sinha, A. (2014). Organizational justice and employee engagement: Exploring the linkage in public sector banks in India. Personnel Review, 43(4), 628-652. doi: doi:10.1108/PR08-2013-0148

Giles, M., Parker, V., Mitchell, R., \& Conway, J. (2017). How do nurse consultant job characteristics impact on job satisfaction? An Australian quantitative study. BMC Nursing, 16(1), 51. doi: 10.1186/s12912-017-0246-y

Hackman, J. R., \& Oldham, G. R. (1976). Motivation through the design of work: Test of a theory. Organizational Behavior and Human Performance, 16(2), 250-279. doi: https://doi.org/10.1016/0030-5073(76)90016-7

Hadi, R., \& Adil, A. (2010). Job characteristics as predictors of work motivation and job satisfaction of bank employees. Journal of the Indian Academy of Applied Psychology, 36(2), 294-299.

Hakanen, J. J., Schaufeli, W. B., \& Ahola, K. (2008). The Job Demands-Resources model: A three-year cross-lagged study of burnout, depression, commitment, and work engagement. Work and Stress, 22(3), 224-241.

Harari, M. B., Thompson, A. H., \& Viswesvaran, C. (2018). Extraversion and job satisfaction: The role of trait bandwidth and the moderating effect of status goal attainment. Personality and Individual Differences, 123, 14-16. doi: https://doi.org/10.1016/j.paid.2017.10.041

Hauff, S., Richter, N. F., \& Tressin, T. (2015). Situational job characteristics and job satisfaction: The moderating role of national culture. International business review, 24(4), 710-723. doi: https://doi.org/10.1016/j.ibusrev.2015.01.003

Haynes, B. P. (2007). Office productivity: a shift from cost reduction to human contribution. Facilities, 25(11/12), 452-462. doi: doi:10.1108/02632770710822562

Hobfoll, S. E. (1989). Conservation of resources: A new attempt at conceptualizing stress. American Psychologist, 44(3), 513-524. doi: 10.1037/0003-066X.44.3.513

Hoonakker, P., Marian, A., \& Carayon, P. (2004). The relation between job characteristics and quality of working life: The role of task identity to explain gender and job type differences. Paper presented at the Proceedings of the Human Factors and Ergonomics Society Annual Meeting.

Ilies, R., \& Judge, T. A. (2002). Understanding the dynamic relationships among personality, mood, and job satisfaction: A field experience sampling study. Organizational Behavior and Human Decision Processes, 89(2), 1119-1139. doi: https://doi.org/10.1016/S0749-5978(02)00018-3

International Labour Organization (ILO). (2017). Employment distribution by occupation. Retrieved from: https://www.ilo.org

Janssen, O. (2001). Fairness Perceptions as a Moderator in the Curvilinear Relationships Between Job Demands, and Job Performance and Job Satisfaction. Academy of Management Journal, 44(5), 1039-1050. doi: 10.5465/3069447

Jin, X., Sun, I. Y., Jiang, S., Wang, Y., \& Wen, S. (2018). The relationships between job and organizational characteristics and role and job stress among Chinese community correctional workers. International Journal of Law, Crime and Justice, 52, 36-46. doi: https://doi.org/10.1016/j.ijlcj.2017.09.002 
INTERNATIONAL JOURNAL OF ACADEMIC RESEARCH IN BUSINESS AND SOCIAL SCIENCES

Vol. 10, No. 9, 2020, E-ISSN: 2222-6990 @ 2020 HRMARS

Johari, J., \& Yahya, K. K. (2016). Job characteristics, work involvement, and job performance of public servants. European Journal of Training and Development, 40(7), 554-575. doi: https://doi.org/10.1108/EJTD-07-2015-0051

Judge, T. A., Thoresen, C. J., Bono, J. E., \& Patton, G. K. (2001). The job satisfaction-job performance relationship: A qualitative and quantitative review. Psychological Bulletin, 127(3), 376. doi: http://dx.doi.org/10.1037/0033-2909.127.3.376

Kim, W. H., Ra, Y.-A., Park, J. G., \& Kwon, B. (2017). Role of burnout on job level, job satisfaction, and task performance. Leadership \& Organization Development Journal, 38(5), 630-645. doi: https://doi.org/10.1108/LODJ-11-2015-0249

Lambert, E. G., Hogan, N. L., \& Griffin, M. L. (2007). The impact of distributive and procedural justice on correctional staff job stress, job satisfaction, and organizational commitment. Journal of Criminal Justice, 35(6), 644-656. doi: https://doi.org/10.1016/j.jcrimjus.2007.09.001

Lawler, E. E., \& Hall, D. T. (1970). Relationship of job characteristics to job involvement, satisfaction, and intrinsic motivation. Journal of Applied Psychology, 54(4), 305.

Locke, E. A. (1976). The nature and causes of job satisfaction.

McFarlin, D. B., \& Sweeney, P. D. (1992). Distributive and procedural justice as predictors of satisfaction with personal and organizational outcomes. Academy of Management Journal, 35(3), 626-637. doi: https://doi.org/10.5465/256489

Moorman, R. H., Niehoff, B. P., \& Organ, D. W. (1993). Treating employees fairly and organizational citizenship behavior: Sorting the effects of job satisfaction, organizational commitment, and procedural justice. Employee responsibilities and rights journal, 6(3), 209-225.

Nadiri, H., \& Tanova, C. (2010). An investigation of the role of justice in turnover intentions, job satisfaction, and organizational citizenship behavior in hospitality industry. International journal of hospitality management, 29(1), 33-41. doi: https://doi.org/10.1016/j.ijhm.2009.05.001

O'Grady, S. (2017). UK workers have one of the lowest levels of job satisfaction in the World. Retrieved 16 August 2018, 2017, from https://www.express.co.uk

Pee, L. G., \& Chua, A. Y. K. (2015). Duration, frequency, and diversity of knowledge contribution: differential effects of job characteristics. doi: https://doi.org/10.1016/j.im.2015.10.009

Podsakoff, P. M., \& Organ, D. W. (1986). Self-Reports in Organizational Research: Problems and Prospects. Journal of Management, 12(4), 531-544. doi: 10.1177/014920638601200408

Rudolph, C. W., Katz, I. M., Lavigne, K. N., \& Zacher, H. (2017). Job crafting: A meta-analysis of relationships with individual differences, job characteristics, and work outcomes. Journal of Vocational Behavior, 102, 112-138. doi: https://doi.org/10.1016/j.jvb.2017.05.008

Saavedra, R., \& Kwun, S. K. (2000). Affective states in job characteristics theory. Journal of Organizational Behavior: The International Journal of Industrial, Occupational and Organizational Psychology and Behavior, 21(2), 131-146. doi: https://doi.org/10.1002/(SICI)1099-1379(200003)21:2<131::AID-JOB39>3.0.CO;2-Q

Selig, J. P., \& Preacher, K. J. (2008). Monte Carlo method for assessing mediation: An interactive tool for creating confidence intervals for indirect effects [Computer software].

Shin, D. S., Jeong, B. Y., \& Park, M. H. (2018). Structural equation modeling of office environment quality, sick building syndrome, and musculoskeletal complaints on aggregate satisfaction of office workers. Human Factors and Ergonomics in Manufacturing \& Service Industries, 28(3), 148-153. doi: https://doi.org/10.1002/hfm.20730 
INTERNATIONAL JOURNAL OF ACADEMIC RESEARCH IN BUSINESS AND SOCIAL SCIENCES

Vol. 10, No. 9, 2020, E-ISSN: 2222-6990 @ 2020 HRMARS

Shore, L. M., \& Martin, H. J. (1989). Job Satisfaction and Organizational Commitment in Relation to Work Performance and Turnover Intentions. Human Relations, 42(7), 625-638. doi: 10.1177/001872678904200705

Simmering, M. J., Colquitt, J. A., Noe, R. A., \& Porter, C. O. (2003). Conscientiousness, autonomy fit, and development: A longitudinal study. Journal of Applied Psychology, 88(5), 954. doi: http://dx.doi.org/10.1037/0021-9010.88.5.954

Spell, C. S. (2009). How does distributive justice affect work attitudes? The moderating effects of autonomy AU - Haar, Jarrod M. The International Journal of Human Resource Management, 20(8), 1827-1842. doi: 10.1080/09585190903087248

Strom, D. L., Sears, K. L., \& Kelly, K. M. (2014). Work Engagement. Journal of Leadership \& Organizational Studies, 21(1), 71-82. doi: doi:10.1177/1548051813485437

Szeto, G. P. Y., Straker, L., \& Raine, S. (2002). A field comparison of neck and shoulder postures in symptomatic and asymptomatic office workers. Applied Ergonomics, 33(1), 75-84. doi: https://doi.org/10.1016/S0003-6870(01)00043-6

Tella, A., Ayeni, C., \& Popoola, S. (2007). Work motivation, job satisfaction, and organisational commitment of library personnel in academic and research libraries in Oyo State, Nigeria. Library Philosophy and Practice (e-journal), 118.

UK Labour Force Survey. (2017). Employment by Status, Occupation \& Sex. Retrieved from: https://www.ons.gov.uk

Wickramasinghe, V. (2009). Predictors of job satisfaction among IT graduates in offshore outsourced IT firms. Personnel Review, 38(4), 413-431. doi: https://doi.org/10.1108/00483480910956355

Yang, C.-L., \& Hwang, M. (2014). Personality traits and simultaneous reciprocal influences between job performance and job satisfaction. Chinese Management Studies, 8(1), 6-26. doi: https://doi.org/10.1108/CMS-09-2011-0079

Yang, J.-S., \& Hung, H. V. (2017). Happy workers value effort, sad workers value reward. The International Journal of Human Resource Management, 28(11), 1591-1624. doi: 10.1080/09585192.2015.1128458

Younts, C. W., \& Mueller, C. W. (2001). Justice processes: Specifying the mediating role of perceptions of distributive justice. American Sociological Review, 125-145. doi: 10.2307/2657396 